Article

\title{
Anti-Inflammatory Activity of Heterocarpin from the Salt Marsh Plant Corydalis heterocarpa in LPS-Induced RAW 264.7 Macrophage Cells
}

\author{
You Ah Kim ${ }^{1}$, Chang-Suk Kong ${ }^{2}$, Hyo Hyun Park ${ }^{3}$, Eunkyung Lee ${ }^{3}$, Mi-Soon Jang ${ }^{4}$, \\ Ki-Ho Nam ${ }^{4}$ and Youngwan Seo ${ }^{1,5, *}$
}

1 Division of Marine Bioscience, Korea Maritime \& Ocean University, Busan 606-791, Korea; E-Mail: ahyou2@hanmail.net

2 Department of Food and Nutrition, Silla University, Busan 617-736, Korea; E-Mail: cskong@silla.ac.kr

3 Research and Development Division, Korea Promotion Institute for Traditional Medicine Industry, Gyeongsan 712-260, Korea; E-Mails: qkrgygus@empal.com (H.H.P.); eklee@ynu.ac.kr (E.L.)

4 Food and Safety Research Center, National Fisheries Research \& Development Institute, Busan 619-705, Korea; E-Mails: suni1@korea.kr (M.-S.J.); dennis011@korea.kr (K.-H.N.)

5 Ocean Science \& Technology School, Korea Maritime \& Ocean University, Busan 606-791, Korea

* Author to whom correspondence should be addressed; E-Mail: ywseo@kmou.ac.kr; Tel.: +82-51-410-4328; Fax: +82-51-404-3538.

Academic Editor: Maurizio Battino

Received: 11 June 2015 / Accepted: 30 July 2015 / Published: 10 August 2015

\begin{abstract}
The inhibitory effect of three chromones 1-3 and two coumarins 4-5 on the production of nitric oxide (NO) was evaluated in LPS-induced RAW 264.7 macrophage cells. Among the compounds tested heterocarpin (1), a furochromone, significantly inhibited its production in a dose-dependent manner. In addition, heterocarpin suppressed prostaglandin $\mathrm{E}_{2}\left(\mathrm{PGE}_{2}\right)$ production and expression of cytokines such as inducible nitric oxide synthase (iNOS), cyclooxygenase-2 (COX-2), tumor necrosis factor- $\alpha$ (TNF- $\alpha$ ), interleukin-1 $\beta$ (IL-1 $\beta$ ) and interleukin-6 (IL-6).
\end{abstract}

Keywords: Corydalis heterocarpa; heterocarpin; furochromone; anti-inflammatory effect 


\section{Introduction}

Halophytes are naturally salt-tolerant plants that may be potentially useful as new sources of biologically active substances. These plants are exposed in their habitats to various abiotic constraints (salinity, drought, heat/cold, luminosity and other harsh environmental conditions), and as a result, they have had to adapt to their environment by developing specific responses which often include the synthesis of unusual secondary metabolites. Corydalis heterocarpa is a salt-tolerant plant species that grows on sandy seashores throughout the western coastal area of South Korea. The genus Corydalis is composed of more than 400 species in Eurasia and North America. For centuries some Corydalis species have been long used for the treatment of ailments in Asian countries including China, Korea, and Japan. C. heterocarpa has been also used in Korean folk medicine to treat labor pains, spasms, boils, and dysentery. Nevertheless, only a few studies of this species have been reported. To date C. heterocarpa has been shown to possess UVB-protection, anti-tumor, anti-oxidant and anti-inflammatory effects. These effects seem to be due to coumarins, promoting them as a source of biofunctional products [1-5]. Like other salt marsh plants, a high content of phytochemicals which are crucially needed to endure the highly salinic environmental conditions is a characteristic of $C$. heterocarpa. Coupled with the high potential of phytochemicals and high rates of nutritional consumption, the utilization of $C$. heterocarpa as a functional food has been suggested. In this regard, research on the secondary metabolites and bioactivities of the $C$. heterocarpa has not been done intensely enough.

In the present study, the anti-inflammatory effect of three chromones 1-3 and two coumarins 4-5 isolated from $C$. heterocarpa was assessed by measuring NO production in LPS-stimulated RAW 264.7 cells. Furthermore, production of iNOS, PGE2, TNF- $\alpha$, IL-1 $\beta$, IL-6, and COX-2 on heterocarpin-treated RAW 264.7 macrophage cells was investigated.

\section{Results and Discussion}

\subsection{Isolation and Structure Determination of Compounds 1-5}

Shade-dried whole plants of Corydalis heterocarpa were extracted twice overnight with $\mathrm{CH}_{2} \mathrm{Cl}_{2}$ and $\mathrm{MeOH}$ at room temperature. The combined crude extracts were concentrated in vacuo at $40{ }^{\circ} \mathrm{C}$ to leave a dark brown gum and then partitioned between $\mathrm{CH}_{2} \mathrm{Cl}_{2}$ and $\mathrm{H}_{2} \mathrm{O}$. Each layer was further partitioned with $n$-hexane $/ 85 \%$ aq. $\mathrm{MeOH}$ and $n-\mathrm{BuOH} / \mathrm{H}_{2} \mathrm{O}$, respectively. The $n$ - $\mathrm{BuOH}$ and $85 \%$ aq. $\mathrm{MeOH}$ fractions were purified by various column chromatographies, TLC and HPLC methods using different solvent combinations to yield three chromones and two coumarins (Figure 1A).

Compounds 1-5 were identified by a combination of spectroscopic analysis and comparison with previously reported data as heterocarpin (1), cnidimol A (2), cnidimoside A (3), isopimpinellin (4) and hyunganol II (5), respectively [6-9].

\subsection{Cell Viability}

We first measured the cytotoxicity of compounds $\mathbf{1 - 5}$ in RAW 264.7 cells by using the MTT assay. The result showed compounds $\mathbf{1}-\mathbf{5}$ at the concentrations used (50 and $100 \mu \mathrm{M})$ had no cytotoxic effect, except compound 4 at a concentration of $100 \mu \mathrm{M}$ (Figure 1B). 
A<smiles>C=C(S)C1Cc2c(cc3oc(C)cc(=O)c3c2O)O1</smiles><smiles>[R9]OC([B])=CCc1c(O)cc2oc(C)cc(=O)c2c1O</smiles>

$2 \mathrm{R}=\mathrm{H}$

$3 \mathrm{R}=\mathrm{glu}$<smiles>COc1c2ccoc2c(OC)c2oc(=O)ccc12</smiles>

4

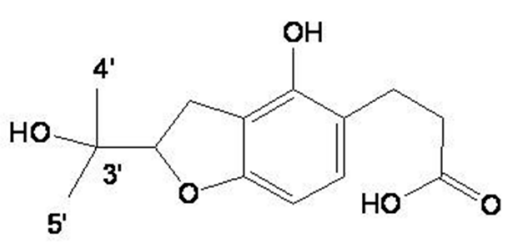

5

B

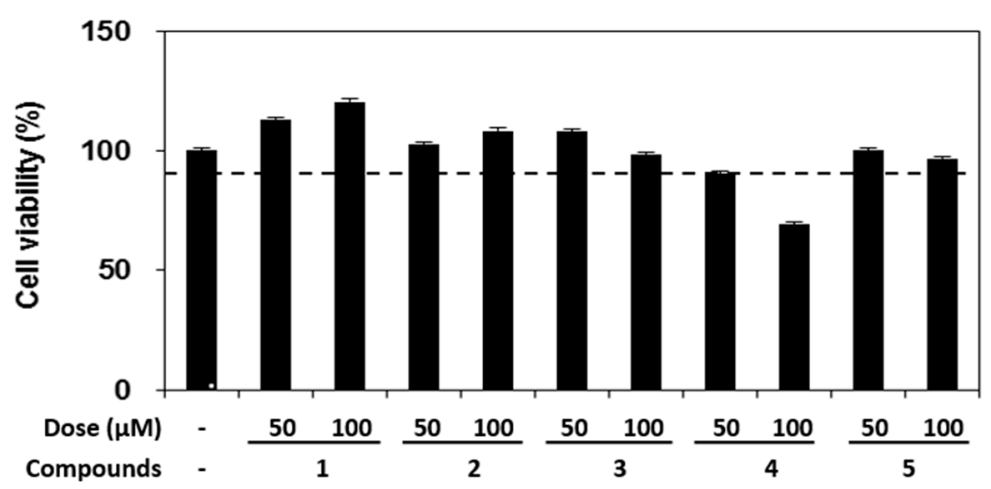

Figure 1. Chemical structure (A) and effect on cell viability (B) of compounds $\mathbf{1}-\mathbf{5}$ isolated from Corydalis heterocarpa on RAW 264.7 cells. RAW 264.7 cells were treated with 50 and $100 \mu \mathrm{M}$ of compounds $\mathbf{1}-\mathbf{5}$ for $1 \mathrm{~h}$ prior to the addition of LPS $(100 \mathrm{ng} / \mathrm{mL})$, and the cells were further incubated for $24 \mathrm{~h}$. Data are presented as means \pm SD of three independent experiments.

\subsection{Effect of Compounds 1-5 on LPS-induced NO Production and iNOS Expression}

To investigate the inhibitory effect of compounds $\mathbf{1}-\mathbf{5}$ on NO production, RAW 264.7 cells were pretreated with each compound for $1 \mathrm{~h}$ prior to stimulation with LPS. Following $24 \mathrm{~h}$ of LPS stimulation, the levels of NO production in the culture media were measured. As shown in Figure 2A, LPS stimulation resulted in a marked induction of NO production when compared to the untreated cells and pretreatment with compound 1 suppressed the NO production with an $\mathrm{IC}_{50}$ value of $66.6 \mu \mathrm{M}$ (Figure 2B), whereas other compounds did not reduce nitrite levels (Figure 2A). To determine whether suppression of NO production by compound 1 was due to reduced iNOS protein expression, cells were pretreated with different concentrations of compound 1 and stimulated with LPS for $24 \mathrm{~h}$. The significant induction of iNOS protein by LPS stimulation was inhibited by compound $\mathbf{1}$ in a dose-dependent manner (Figure 2C). These results showed that compound $\mathbf{1}$ inhibited NO production by the decreased iNOS protein expression. 
A

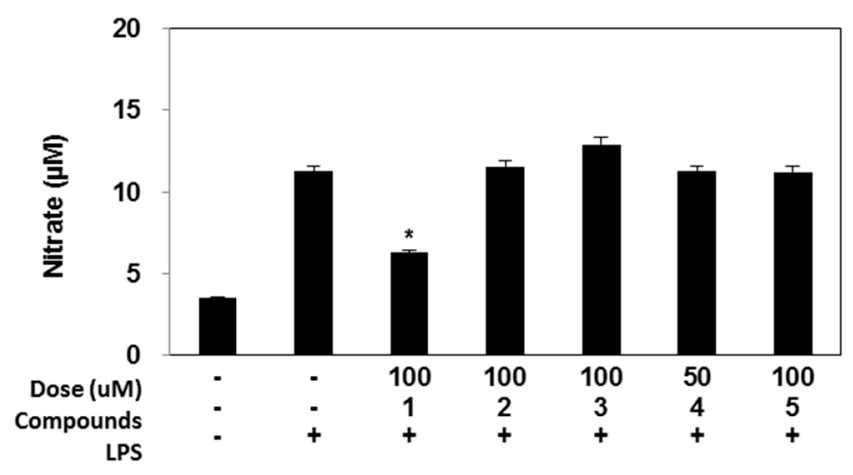

B

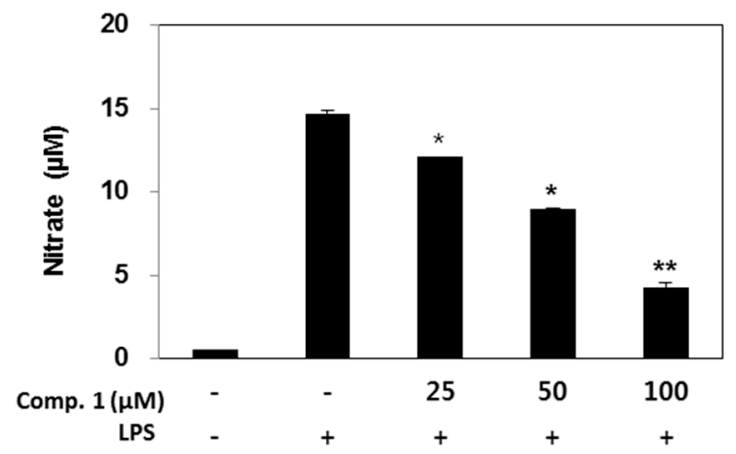

C

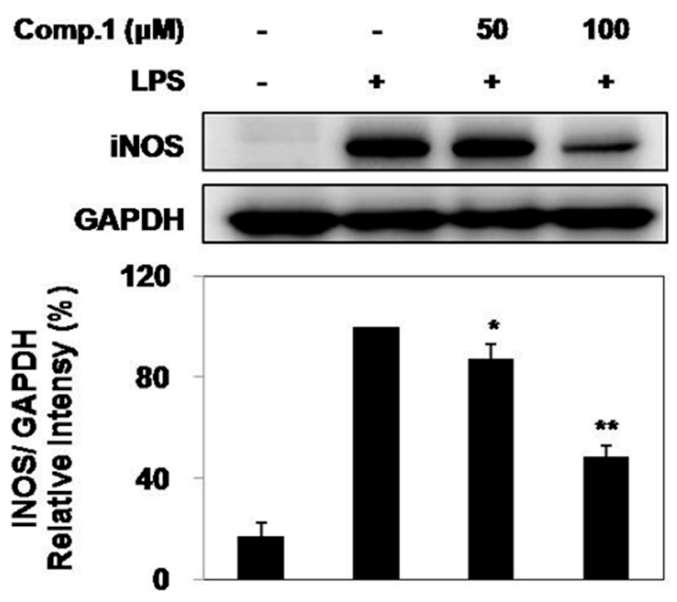

Figure 2. Effects of compounds 1-3, $5(100 \mu \mathrm{M})$ and $4(50 \mu \mathrm{M})(\mathbf{A})$, and compound $\mathbf{1}$ $(25-100 \mu \mathrm{M})(\mathbf{B})$ on NO production by means of nitrite concentration and iNOS expression by means of protein expression levels (C) in LPS induced RAW 264.7 cells. RAW 264.7 cells were cultured with LPS $(100 \mathrm{ng} / \mathrm{mL})$ in the presence or absence of compounds $\mathbf{1}-\mathbf{5}$ for $24 \mathrm{~h}$ to determine the level of NO. The data represent the mean $\pm \mathrm{SD}$ of three separate experiments (significant as compared to control. $* p<0.05$ and $* * p<0.01$ ).

\subsection{Effect of Compound 1 on LPS-Induced PGE2 Production and COX-2 Expression}

To further elucidate the anti-inflammatory response of compound $\mathbf{1}$, we examined the inhibitory effect of compounds 1 on PGE2 production following LPS stimulation in RAW 264.7 cells. Briefly, the cells were pretreated with various concentrations of compound $\mathbf{1}$ for $1 \mathrm{~h}$ and then stimulated with LPS. After incubation for $24 \mathrm{~h}$, the production of $\mathrm{PGE}_{2}$ from the culture supernatant was measured using ELISA. As shown in Figure 3A, the amount of $\mathrm{PGE}_{2}$ in the culture supernatant increased with LPS stimulation, 
and then this increase was reduced by treatment with compound 1 in a dose-dependent manner $(p<0.05)$. To investigate whether the inhibitory effects of compound $\mathbf{1}$ on $\mathrm{PGE}_{2}$ production are related to the modulation of the COX-2 expression, we evaluated the COX-2 protein levels using Western blot analysis. The COX-2 protein was not detected in the absence of LPS stimulation, but the levels of COX-2 were induced after LPS exposure. As shown in Figure 3B, compound 1 reduced LPS-stimulated COX-2 protein expression.

A

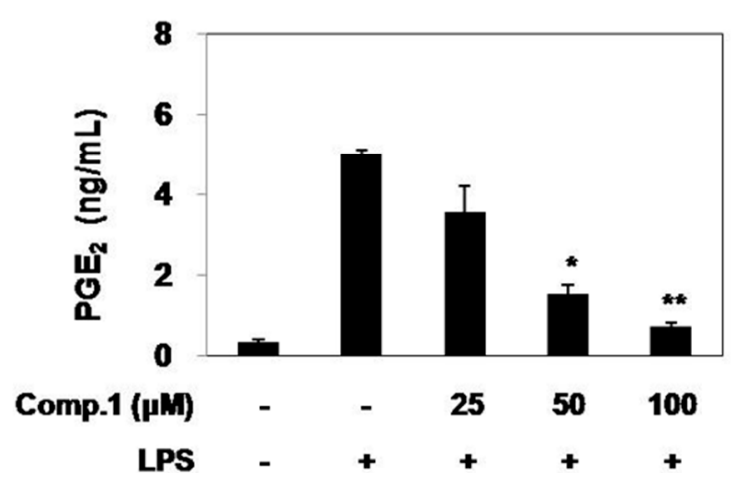

B

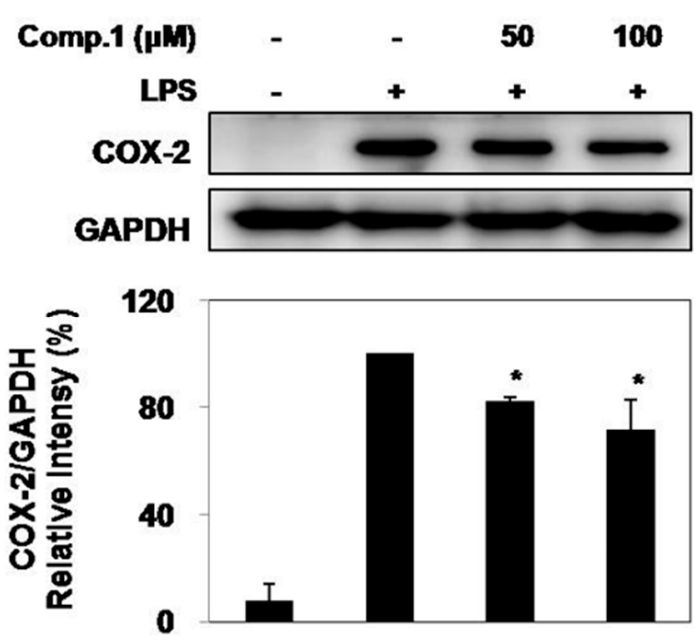

Figure 3. Effects of compound 1 on production of $\mathrm{PGE}_{2}$ (A) and COX-2 expression (B) in LPS induced RAW 264.7 cells. RAW 264.7 cells were treated with different concentrations $(25,50,100 \mu \mathrm{M})$ of compound 1 for $1 \mathrm{~h}$ prior to stimulation with $100 \mathrm{ng} / \mathrm{mL}$ of LPS for $24 \mathrm{~h}$. Control values were obtained in the absence of LPS or compound 1. The values are the mean $\pm \mathrm{SD}$ of three independent experiments (significant as compared to control. ${ }^{*} p<0.05$ and $* * p<0.01)$

\subsection{Effects of Compound 1 on Pro-Inflammatory Cytokine Production}

To further determine the anti-inflammatory effect of compound $\mathbf{1}$, the secreted pro-inflammatory cytokines, such as TNF- $\alpha$, IL-1 $\beta$ and IL- 6 were measured by ELISA. Treatment of RAW 264.7 cells with LPS alone resulted in a marked induction of cytokine production when compared to the untreated cells $(p<0.001)$ (Figure 4). However, the pretreatment of compound 1 at $100 \mu \mathrm{M}$ significantly decreased TNF- $\alpha$ levels compared to the supernatant of the LPS-stimulated cells $(p<0.05)$. In addition, the levels of IL- $1 \beta$ and IL- 6 were increased in the culture supernatant of the LPS-stimulated cells whereas pretreatment with compound 1 at 50 and $100 \mu \mathrm{M}$ resulted in a decrease in cytokine production $(p<0.05$ or 0.01$)$.

\subsection{Discussion}

In recent years, there has been much interest in and research on the influence of natural products on several diseases, including aging-related illness, cancer, neurodegenerative disease, and cardiovascular disease. Corydalis species have been extensively investigated for this purpose, and have yielded alkaloids, isoquinoline alkaloids, and cyanidin glycosides as their secondary metabolites [10-12]. Corydalis heterocarpa has been widely used as a folk medicine for treatment of labor pains, spasms, boils and dysentery [2-5]. Macrophages play an important role in inflammatory disorders through the 
release of factors such as NO, cytokines, and prostaglandin mediators in the immune system [13-16]. The inducible form of NO is generated from L-arginine by iNOS. NO, a free radical, plays important roles in a variety of physiological functions such as host defense, vasodilation, and regulation of cellular functions $[17,18]$. However, overproduction of NO by iNOS further enhances cyclooxygenase 2 (COX-2) activities, and can be deleterious to the host [19-21]. COX-2 is a highly inducible enzyme that catalyzes the conversion of arachidonic acid into prostaglandins (PGs) during inflammation. One of the PGs produced at high levels in inflammation is prostaglandin $\mathrm{E}_{2}\left(\mathrm{PGE}_{2}\right)$, a major COX-2 product at inflammatory sites, which contributes to local blood flow increases, edema formation, and pain sensitization [22,23].

A

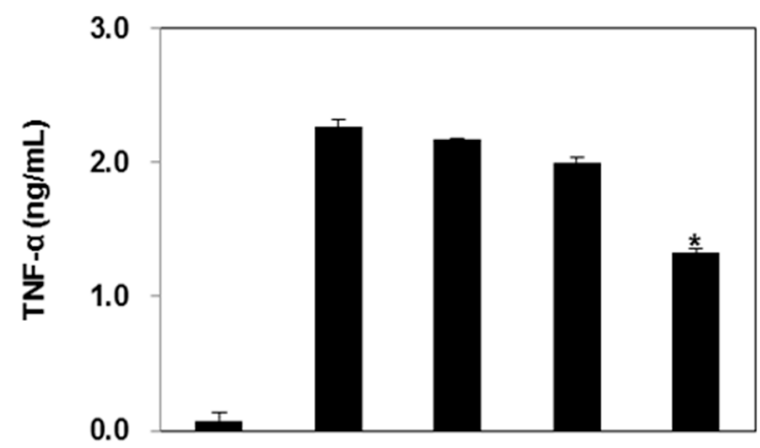

B

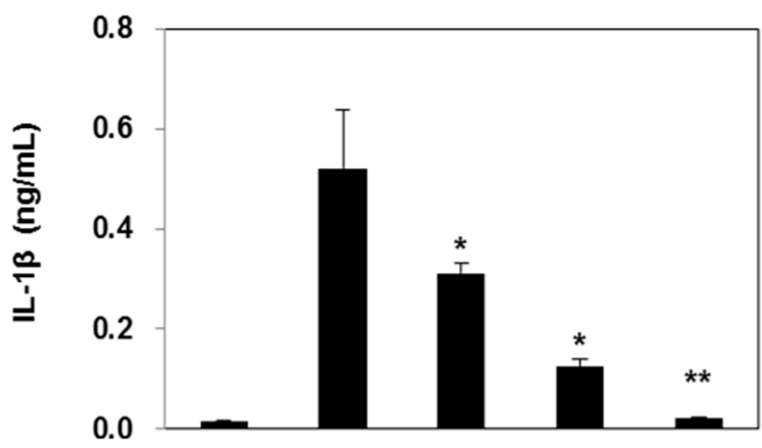

C

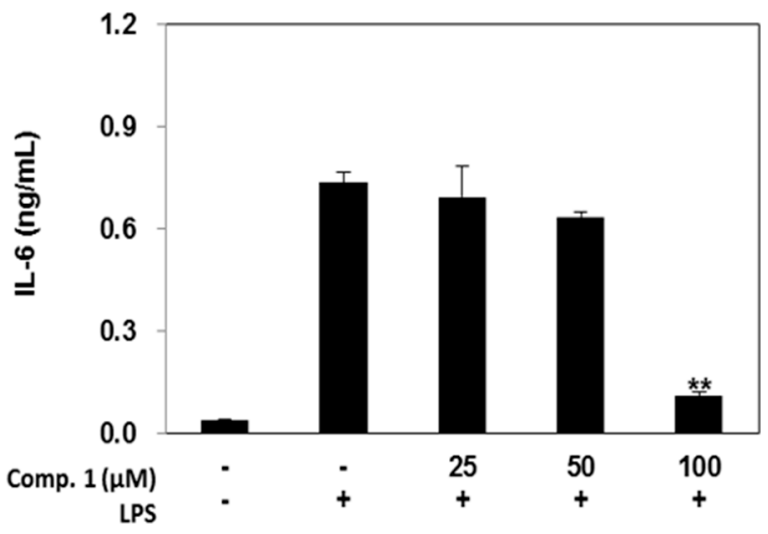

Figure 4. Effect of compound 1 on the production of cytokines stimulated by LPS. Production of TNF- $\alpha$ (A), IL-1 $\beta$ (B) and IL-6 (C) were measured in the medium of RAW 264.7 cells cultured with LPS $(100 \mathrm{ng} / \mathrm{mL})$ in the presence or absence of compound 1 for $24 \mathrm{~h}$. Data represent the mean $\pm \mathrm{SD}$ with three separate experiments (significant as compared to control. $* p<0.05, * * p<0.01)$.

Five compounds from Corydalis heterocarpa were screened for their ability to inhibit LPS-induced NO production in RAW 264.7 macrophages at a concentration of $100 \mu \mathrm{M}$. This activity was not 
attributable to cytotoxicity of $\mathbf{1 - 5}$ as confirmed by the MTT assay, which showed little cytotoxicity for any of these compounds at the screened concentrations. Among the compounds tested, heterocarpin (1) most strongly inhibited NO production, so heterocarpin was further investigated for its inhibitory effect on production of $\mathrm{PGE}_{2}$, the major metabolite of the COX-2 pathway, which plays a critical role in the pathogenesis of acute and chronic inflammatory diseases [24,25]. PGE2 production was prominently decreased by heterocarpin, showing inhibition rate of $85.5 \%$ at a concentration of $100 \mu \mathrm{M}$. To confirm the underlying mechanism of this potent effect, we examined its effect on protein expression of both iNOS and COX-2 enzymes, which are known to be responsible for NO and $\mathrm{PGE}_{2}$ production, respectively. We found that heterocarpin suppressed LPS-induced iNOS and COX-2 protein expression. This means that the inhibition of $\mathrm{NO}$ and $\mathrm{PGE}_{2}$ production by heterocarpin is a result of the inhibition of the iNOS and COX-2 expression.

$\mathrm{NO}$ and $\mathrm{PGE}_{2}$ are known to act as secondary mediators of pro-inflammatory cytokines, such as TNF- $\alpha$, IL-1 $\beta$ and IL-6, which are considered to be important initiators of the inflammatory response and mediators of the development of various inflammatory diseases [26,27]. Among these, TNF- $\alpha$ is implicated as a key cytokine playing an important role in the immune response such as autoimmune reactions, and its production is crucially required for the synergistic induction of NO synthesis in LPS-stimulated macrophages [28]. IL-1 $\beta$ is also an important mediator of the inflammatory response produced by activated macrophages, and is involved in a variety of cellular activities such as cell proliferation, differentiation, and apoptosis. Likewise, IL-6 plays a role as a crucial pro-inflammatory cytokine, regarded as an endogenous mediator of LPS-induced fever [15,16,29-31]. In this study, heterocarpin inhibited production of TNF- $\alpha$, IL-1 $\beta$, and IL- 6 in a dose dependent manner in LPS-stimulated RAW 264.7 cells. In particular, IL-1 $\beta$ production was greatly decreased by heterocarpin, with an inhibition ratio of $95.7 \%$ at a concentration of $100 \mu \mathrm{M}$.

In conclusion, these results suggest that heterocarpin suppresses the production of $\mathrm{NO}, \mathrm{PGE}_{2}$, and pro-inflammatory cytokines TNF- $\alpha$, IL- $1 \beta$ and IL- 6 by reducing their protein expression levels as measured by western blot analysis. Therefore, heterocarpin may be useful for the treatment of inflammatory diseases, although further studies are needed to elucidate the mechanism of its in vivo anti-inflammatory activity.

\section{Experimental Section}

\subsection{General Procedures}

Optical rotation was determined on a Perkin-Elmer polarimeter 341 (The Perkin-Elmer Co., Norwalk, $\mathrm{CT}$, USA) using a $1 \mathrm{~cm}$ cell. NMR spectra were recorded in $\mathrm{CD}_{3} \mathrm{OD}$ and $\mathrm{CDCl}_{3}$ on a Varian Mercury 300 instrument (Varian, Palo Alto, CA, USA) at $300 \mathrm{MHz}$ for ${ }^{1} \mathrm{H}$ and $75 \mathrm{MHz}$ for ${ }^{13} \mathrm{C}$ using standard pulse sequence programs. All chemical shifts were recorded with respect to TMS as an internal standard. Mass spectroscopic data were obtained at the Korean Basic Science Institute, Seoul, Korea. High performance liquid chromatography (HPLC) was performed with a Dionex P580 (Dionex Corp., Sunnyvale, CA, USA) with a Varian 350 RI detector (Varian, Walnut Creek, CA, USA). All solvents used were spectroscopic grade or were distilled from glass prior to use. 


\subsection{Reagents}

Dulbecco's modified Eagle's medium (DMEM), fetal bovine serum (FBS), penicillin-streptomycin and other reagents for cell culture were obtained from Gibco (Invitrogen, Carlsbad, CA, USA). 3-(4,5Dimethylthiazol-2-yl)-5-(3-carboxymethoxphenyl)-2-(4-sulfopheny)-2H-tetrazolium (MTS) was obtained from Promega (Madison, WI, USA). Lipopolysaccharide (LPS, from Escherichia coli), Griess reagent and phosphate buffer saline (PBS) were purchased from Sigma Chemical Co. (St. Louis, MO, USA). A $\mathrm{PGE}_{2}$ immunoassay kit was purchased from Cayman Chemical (Ann Arbor, MI, USA). Mouse TNF- $\alpha$, IL-1 $\beta$ and IL-6 and ELISA kits were purchased from R\&D systems (Minneapolis, MN, USA). PRO-PREPTM Protein Extraction Solution was from iNtRON Biotechnology (Kyungki-Do, Korea). The primary antibody for iNOS was obtained from BD Bioscience (San Jose, CA, USA) and COX-2 was purchased from Cayman Chemical. GAPDH and second antibodies were purchased from Santa Cruz Biotechnology (Santa Cruz, CA, USA). Other chemicals were from Sigma-Aldrich (St. Louis, MO, USA).

\subsection{Plant Material}

Whole plants of Corydalis heterocarpa were collected in Muan-gun, Jeollanamdo, Korea in July, 2003. The plant was identified by Sung Gi Moon by its morphological characteristics. A voucher specimen is deposited at the Herbarium of the Department of Marine Environment and Bioscience, Korea Maritime University, Busan, Korea (voucher No. 03H-7).

\subsection{Extraction and Isolation}

The collected samples (300 g) were air-dried, chopped into small pieces, and extracted for 2 days with $\mathrm{MeOH}(3 \mathrm{~L} \times 2)$ and $\mathrm{CH}_{2} \mathrm{Cl}_{2}(3 \mathrm{~L} \times 2)$, respectively. The combined crude extracts $(41.1 \mathrm{~g})$ were evaporated under reduced pressure and partitioned between $\mathrm{CH}_{2} \mathrm{Cl}_{2}$ and water. The organic layer was further partitioned between $85 \%$ aq. $\mathrm{MeOH}$ and $n$-hexane, and the aqueous layer was fractionated with $n$ - $\mathrm{BuOH}$ and $\mathrm{H}_{2} \mathrm{O}$, successively, to afford $n$-hexane (7.3 g), 85\% aqueous $\mathrm{MeOH}$ (12.0 g), $n$ - $\mathrm{BuOH}$ (4.3 g), and water $(20.0 \mathrm{~g})$.

A portion of the $85 \%$ aqueous $\mathrm{MeOH}(6.0 \mathrm{~g})$ fraction was subjected to $\mathrm{C}_{18}$ reversed-phase vacuum flash chromatography using stepwise gradient mixtures of $\mathrm{MeOH}$ and water $(50 \%, 60 \%, 70 \%, 80 \%$, $90 \%$ aq. $\mathrm{MeOH}$, and $100 \% \mathrm{MeOH}$ ) as eluents to give six subfractions. Fraction 3 was subjected by reversed-phase HPLC (YMC ODS-A, 65\% aq. MeOH, $1 \mathrm{~cm} \times 25 \mathrm{~cm}$, S-5 $\mu \mathrm{m}, 2 \mathrm{~mL} / \mathrm{min}$ ) to afford three mixtures containing 1 and 4. Each mixture was further separated by HPLC (YMC ODS-A, 50\% aq. $\mathrm{AcCN})$ to give 4 (13.6 $\mathrm{mg}$ ) and $\mathbf{1}(6.4 \mathrm{mg})$, respectively.

A half of the $n$-BuOH $(2.2 \mathrm{~g})$ fraction was also subjected to $\mathrm{C}_{18}$ reversed-phase vacuum flash chromatography using the same solvent mixtures as that of the $85 \%$ aqueous $\mathrm{MeOH}$ fraction to give six subfractions. Fraction 1 was further separated by Si gel column chromatography with stepwise gradient mixtures of $\mathrm{MeOH}$ and $\mathrm{CHCl}_{3}\left(0 \%, 5 \%, 10 \%, 20 \%, 30 \%, 40 \%, 50 \%, 70 \%, 100 \% \mathrm{MeOH}\right.$ in $\left.\mathrm{CHCl}_{3}\right)$ as eluents to give 9 subfractions. The fourth fraction was separated by preparative TLC on a Si gel chromatograph with EtOAc/ $\mathrm{MeOH} / \mathrm{H}_{2} \mathrm{O}(23: 4: 3)$ to afford $5(6.9 \mathrm{mg})$ and two mixtures, which were separated by reversed-phase HPLC (YMC ODS-A, 43 and 60\% aq. MeOH) to give 2 (6.8 $\mathrm{mg}$ ) and 3 (4.5 mg), respectively. 
Heterocarpin (1): Amorphous white solid; $\mathrm{mp} 155-158^{\circ} \mathrm{C} ;[\alpha]_{\mathrm{D}}^{20}+20^{\circ}(c 0.25, \mathrm{MeOH})$; HRFABMS $m / z$ $259.0970[\mathrm{M}+\mathrm{H}]^{+}$(calcd. for $\left.\mathrm{C}_{15} \mathrm{H}_{14} \mathrm{O}_{4}, 259.0970\right) ;{ }^{1} \mathrm{H}-\mathrm{NMR}\left(\mathrm{CD}_{3} \mathrm{OD}\right) \delta: 6.33(1 \mathrm{H}, \mathrm{s}, \mathrm{H}-8), 6.03(1 \mathrm{H}$, s, H-3), 4.74 (1H, s, H-4'a), 4.68 (1H, s, H-4'b), 4.38 (1H, t, $\left.J=6.6 \mathrm{~Hz}, \mathrm{H}-2^{\prime}\right), 2.98(1 \mathrm{H}, \mathrm{dd}$, $\left.J=6.6,13.48 \mathrm{~Hz}, \mathrm{H}-1^{\prime} \mathrm{a}\right), 2.85$ (1H, dd, $\left.J=6.6,13.48 \mathrm{~Hz}, \mathrm{H}-1^{\prime} \mathrm{b}\right), 2.34$ (3H, s, 2-Me), 1.81 (3H, s, H-5');

${ }^{13} \mathrm{C}-\mathrm{NMR}(\mathrm{CD}$ OD) $\delta: 183.8$ (C, C-4), 164.2 (C, C-7), 168.8 (C, C-2), 160.5 (C, C-5), 157.9 (C, C-9), 148.5 (C, C-3'), 110.2 (C, C-6), $111.0\left(\mathrm{CH}_{2}, \mathrm{C}-4\right.$ '), 108.7 (CH, C-3), 104.7 (C, C-10), 94.4 (CH, C-8), $76.2\left(\mathrm{CH}, \mathrm{C}-2^{\prime}\right), 29.7\left(\mathrm{CH}_{2}, \mathrm{C}-1^{\prime}\right), 20.3\left(\mathrm{CH}_{3}, 2-\mathrm{Me}\right), 17.8\left(\mathrm{CH}_{3}, \mathrm{C}-5^{\prime}\right)$.

Cnidimol A (2): Amorphous white solid; $[\alpha]_{\mathrm{D}}^{20}-18.00^{\circ}\left(c 0.50\right.$, MeOH); ESIMS $m / z 277[\mathrm{M}+\mathrm{H}]^{+} ;{ }^{1} \mathrm{H}-\mathrm{NMR}$ $\left(\mathrm{CD}_{3} \mathrm{OD}\right) \delta: 7.21(1 \mathrm{H}, \mathrm{s}, \mathrm{H}-8), 6.12(1 \mathrm{H}, \mathrm{s}, \mathrm{H}-3), 5.35\left(1 \mathrm{H}, \mathrm{t}, J=7.7 \mathrm{~Hz}, \mathrm{H}-2^{\prime}\right), 4.31\left(2 \mathrm{H}, \mathrm{s}, \mathrm{H}-5^{\prime}\right), 3.46$ $\left(2 \mathrm{H}, \mathrm{d}, J=7.7 \mathrm{~Hz}, \mathrm{H}-1^{\prime}\right), 2.31$ (3H, s, 2-Me), $1.74\left(3 \mathrm{H}, \mathrm{s}, \mathrm{H}-4^{\prime}\right) ;{ }^{13} \mathrm{C}-\mathrm{NMR}(\mathrm{CD} 3 \mathrm{OD}) \delta: 184.3$ (C, C-4), 169.9 (C, C-2), 159.3 (C, C-7), 157.6 (C, C-5), 156.6 (C, C-9), 135.8 (C, C-3'), 125.4 (CH, C-2'), 116.6 (C, C-6), 109.1 (CH, C-3), 107.6 (C, C-10), $99.8(\mathrm{CH}, \mathrm{C}-8), 61.6\left(\mathrm{CH}_{2}, \mathrm{C}-5{ }^{\prime}\right), 22.5\left(\mathrm{CH}_{2}, \mathrm{C}-1^{\prime}\right), 21.5$ $\left(\mathrm{CH}_{3}, \mathrm{C}-4{ }^{\prime}\right), 20.4\left(\mathrm{CH}_{3}, 2-\mathrm{Me}\right)$.

Cnidimoside A (3): Amorphous white solid; $[\alpha]_{\mathrm{D}}^{20}-3.16^{\circ}(c 0.32, \mathrm{MeOH})$; FABMS $m / z 439[\mathrm{M}+\mathrm{H}]^{+}$; ${ }^{1} \mathrm{H}-\mathrm{NMR}\left(\mathrm{CD}_{3} \mathrm{OD}\right) \delta: 6.29(1 \mathrm{H}, \mathrm{s}, \mathrm{H}-8), 5.98(1 \mathrm{H}, \mathrm{s}, \mathrm{H}-3), 5.46\left(1 \mathrm{H}, \mathrm{t}, J=7.0 \mathrm{~Hz}, \mathrm{H}-2^{\prime}\right), 4.65(1 \mathrm{H}, \mathrm{d}$, $\left.J=12.1 \mathrm{~Hz}, \mathrm{H}-5^{\prime} \mathrm{a}\right), 4.32$ (1H, d, $\left.J=12.1 \mathrm{~Hz}, \mathrm{H}-5^{\prime} \mathrm{b}\right), 4.31$ (1H, br.s, H-1"), 3.89 (1H, dd, $J=1.9,11.6 \mathrm{~Hz}$, H-6"a), $3.72\left(1 \mathrm{H}, \mathrm{dd}, J=4.5,11.6 \mathrm{~Hz}, \mathrm{H}-6^{\prime \prime} \mathrm{b}\right), 3.37\left(1 \mathrm{H}, \mathrm{m}, \mathrm{H}-4^{\prime \prime}\right), 3.35(2 \mathrm{H}, \mathrm{d}, J=7.0 \mathrm{~Hz}$, H-1'), 3.34 (1H, m, H-5"), 3.32 (1H, m, H-3"), 3.21 (1H, m, H-2"), 2.31 (3H, s, 2-Me), 1.76 (3H, s, H-4'); ${ }^{13} \mathrm{C}-\mathrm{NMR}\left(\mathrm{CD}_{3} \mathrm{OD}\right) \delta$ : 183.6 (C, C-4), 168.6 (C, C-2), 164.0 (C, C-7), 159.6 (C, C-5), 157.6 (C, C-9), 132.3 (C, C-3'), 128.7 (CH, C-2'), 112.1 (C, C-6), 108.6 (CH, C-3), 104.5 (C, C-10), $102.3(\mathrm{CH}$, C-1"), $94.3(\mathrm{CH}, \mathrm{C}-8), 78.6\left(\mathrm{CH}, \mathrm{C}-5^{\prime \prime}\right), 77.7\left(\mathrm{CH}, \mathrm{C}-3^{\prime \prime}\right), 75.0\left(\mathrm{CH}, \mathrm{C}-2^{\prime \prime}\right), 71.6\left(\mathrm{CH}, \mathrm{C}-4^{\prime \prime}\right), 68.1\left(\mathrm{CH}_{2}\right.$, $\left.\mathrm{C}-5^{\prime}\right), 62.7\left(\mathrm{CH}_{2}, \mathrm{C}-6^{\prime \prime}\right), 22.0\left(\mathrm{CH}_{2}, \mathrm{C}-1^{\prime}\right), 21.8\left(\mathrm{CH}_{3}, \mathrm{C}-4^{\prime}\right), 20.3\left(\mathrm{CH}_{3}, 2-\mathrm{Me}\right)$.

Isopimpinellin (4): Amorphous white solid; $[\alpha]_{\mathrm{D}}^{25}:+9.52^{\circ}\left(c\right.$ 0.21, MeOH); ${ }^{1} \mathrm{H}-\mathrm{NMR}\left(\mathrm{CD}_{3} \mathrm{OD}\right) \delta: 8.11$ $(1 \mathrm{H}, \mathrm{d}, J=9.9 \mathrm{~Hz}, \mathrm{H}-4), 7.62\left(1 \mathrm{H}, \mathrm{d}, J=2.3 \mathrm{~Hz}, \mathrm{H}-2^{\prime}\right), 7.00\left(1 \mathrm{H}, \mathrm{d}, J=2.3 \mathrm{~Hz}, \mathrm{H}-1^{\prime}\right), 6.28(1 \mathrm{H}, \mathrm{d}$, $J=9.9 \mathrm{~Hz}, \mathrm{H}-3), 4.26\left(3 \mathrm{H}, \mathrm{s}, \mathrm{H}-5-\mathrm{OCH}_{3}\right), 4.15\left(3 \mathrm{H}, \mathrm{s}, \mathrm{H}-8-\mathrm{OCH}_{3}\right) ;{ }^{13} \mathrm{C}-\mathrm{NMR}\left(\mathrm{CDCl}_{3}\right) \delta: 160.4(\mathrm{C}-2)$, 149.8 (C-7), 145.0 (C-2'), 144.1 (C-5), 143.5 (C-9), 139.3 (C-4), 128.0 (C-8), 114.7 (C-6), 112.7 (C-3), $107.5(\mathrm{C}-10), 105.0\left(\mathrm{C}-1^{\prime}\right), 61.7\left(\mathrm{C}-8-\mathrm{OCH}_{3}\right), 60.8\left(\mathrm{C}-5-\mathrm{OCH}_{3}\right)$; EIMS m/z $246[\mathrm{M}]^{+}$.

Hyunganol II (5): Amorphous white solid; $[\alpha]_{\mathrm{D}}^{20}+22.33^{\circ}$ (c 0.36, MeOH); ${ }^{1} \mathrm{H}-\mathrm{NMR}\left(\mathrm{CD}_{3} \mathrm{OD}\right) \delta: 6.76$ $(1 \mathrm{H}, \mathrm{d}, J=8.1 \mathrm{~Hz}, \mathrm{H}-9), 6.17(1 \mathrm{H}, \mathrm{d}, J=8.1 \mathrm{~Hz}, \mathrm{H}-8), 4.53\left(1 \mathrm{H}, \mathrm{t}, J=8.9 \mathrm{~Hz}, \mathrm{H}-2^{\prime}\right), 3.03$ (2H, dd, $\left.J=2.3,8.9 \mathrm{~Hz}, \mathrm{H}-1^{\prime}\right), 2.74(2 \mathrm{H}, \mathrm{t}, J=6.5 \mathrm{~Hz}, \mathrm{H}-4), 2.44$ (2H, t, $\left.J=6.5 \mathrm{~Hz}, \mathrm{H}-3\right), 1.20$ (3H, s, H-4'), 1.22 (3H, s, H-5'); ${ }^{13} \mathrm{C}-\mathrm{NMR}\left(\mathrm{CD}_{3} \mathrm{OD}\right) \delta: 182.5$ (C-2), 160.8 (C-7), 152.8 (C-5), 130.5 (C-9), 123.1 (C-10), 114.9 (C-6), 101.7 (C-8), 90.7 (C-2'), 72.6 (C-3'), 40.4 (C-3), 29.5 (C-1'), 27.5 (C-4), 25.3 $\left.\left(\mathrm{C}-4^{\prime}\right), 25.1\left(\mathrm{C}-5^{\prime}\right)\right)$; FABMS $m / z 267[\mathrm{M}+\mathrm{H}]^{+}$.

\subsection{Cell Culture}

A RAW 264.7 murine macrophage cell line was obtained from the Korean Cell Line Bank (Seoul, Korea) and then cultured in DMEM supplemented with $10 \% \mathrm{FBS}, 100 \mathrm{U} / \mathrm{mL}$ penicillin, $100 \mu \mathrm{g} / \mathrm{mL}$ 
streptomycin, and $100 \mu \mathrm{M}$ MEM non-essential amino acid solution at $37^{\circ} \mathrm{C}$ in a humidified atmosphere of $5 \% \mathrm{CO}_{2}$ and $95 \%$ air.

\subsection{Measurement of Cell Viability}

Cell viability was assessed using the CellTiter 96 Aqueous One kit (Promega). Briefly, RAW 264.7 cells were seeded onto a 96 well plate at $5 \times 10^{4}$ cells/well. After incubation with various concentration of compounds, $20 \mu \mathrm{L}$ of 3-(4,5-dimethylthiazol-2-yl)-5-(3-carboxymethoxyphenyl)-2-(4-sulfopheny)- $2 \mathrm{H}$ tetrazolium (MTS), which is converted to a formazan product by metabolically active cells, was added to each well. After $2 \mathrm{~h}$ of incubation, the optical densities at $490 \mathrm{~nm}$ were measured using a microplate reader (Tecan Systems, San Jose, CA, USA). The compounds were considered to be cytotoxic when the optical density of the sample-treated group was less than $90 \%$ of that in the control group.

\subsection{Measurement of Nitrite and PGE2}

RAW 264.7 cells $\left(2 \times 10^{5}\right.$ cells/well $)$ were seeded onto a 24 -well culture plate at $37{ }^{\circ} \mathrm{C}$ for overnight in medium. The cells were preincubated with different concentrations of the compounds for $1 \mathrm{~h}$ and then incubated for $24 \mathrm{~h}$ with or without LPS. NO production was monitored by measuring nitrite levels in the culture media using Griess reagent (1\% sulfanilamide, $0.1 \% \mathrm{~N}$-1-naphthylenediamine dihydrochloride and $2.5 \%$ phosphoric acid). The absorbance was measured at $570 \mathrm{~nm}$ after incubation for $10 \mathrm{~min}$. The nitrite levels in the samples were calculated from a standard curve generated using known concentrations of sodium nitrite. The $\mathrm{PGE}_{2}$ concentration in the culture supernatant was also measured to determine the inhibitory activities of compound $\mathbf{1}$ using an enzyme immunoassay kit (Cayman Chemical) according to the manufacturer's instructions.

\subsection{Enzyme-Linked Immunosorbent Assay (ELISA)}

RAW 264.7 cells $\left(2 \times 10^{5}\right.$ cells/well) were plated in a 24 -well plate and then incubated with compound 1 for $1 \mathrm{~h}$ in the present or absence of LPS $(100 \mathrm{ng} / \mathrm{mL})$ for $24 \mathrm{~h}$. The supernatants of cell cultures were used to measure the TNF- $\alpha$, IL-1 $\beta$ and IL-6 levels using ELISA kits (R\&D Systems) according to the manufacturer's instructions. The cytokine concentration in the samples was calculated from a standard curve developed using a known concentration of recombinant TNF- $\alpha$, IL-1 $\beta$ and IL-6.

\subsection{Western Blot Analysis}

After activation with LPS, RAW 264.7 cells $\left(2 \times 10^{6}\right.$ cells/well $)$ were washed once with $10 \mathrm{mM}$ PBS (pH 7.4) containing $150 \mathrm{mM} \mathrm{NaCl}$ and then lysed with PRO-PREPTM Protein extraction solution (iNtRON Biotechnology). The protein concentration was determined using the Pierce ${ }^{\circledR} 660 \mathrm{~nm}$ protein assay reagent (Rockford, IL, USA) according to the manufacturer's instructions. Lysates (20 $\mu \mathrm{g} / \mathrm{lane})$ were separated by $10 \%$ SDS-PAGE on polyacrylamide gels and then transferred to polyvinylidene difluoride membranes. Next, the membranes were blocked with 5\% non-fat dry milk or BSA in PBS-T solution for $1 \mathrm{~h}$ and then probed with iNOS (BD Biosciences) and COX-2 antibodies (Cayman Chemical) overnight at $4{ }^{\circ} \mathrm{C}$. The membranes were washed with PBS-T three times and incubated with a secondary 
HRP-conjugated antibody for $2 \mathrm{~h}$ at room temperature. Following three further washings in PBS-T, the protein bands were visualized using an ECL detection reagent (Pierce).

\subsection{Statistical Analysis}

The data were presented as mean $\pm \mathrm{SD}$. The statistical significance of the difference between mean values was determined by the pair $t$-test. $p$-values less than 0.05 or 0.01 were considered statistically significant.

\section{Acknowledgement}

This research was supported by Basic Science Research Program through the National Research Foundation of Korea (NRF) funded by the Ministry of Education (No. 2012R1A1A2002851). Also, this research was financially supported by the National Fisheries Research and Development Institute through the research project entitled "Studies on the environmental-friendly production technique of fusion fish cake and seaweed polysaccharide by fermentation process".

\section{Author Contributions}

E.L. and Y.S. conceived the idea and designed the experiments. Y.A.K., C.S.K., M.S.J and H.H.P. conducted the experiments and analyzed the data. Y.A.K., K.H.N. and Y.S. wrote the manuscript, handled the required revisions and supervised the process.

\section{Conflicts of Interest}

The authors declare no conflict of interest. The founding sponsors had no role in the design of the study; in the collection, analyses, or interpretation of data; in the writing of the manuscript, and in the decision to publish the results.

\section{References}

1. Kim, Y.A.; Kong, C.S.; Yea, S.S.; Seo, Y. Constituents of Corydalis heterocarpa and their anti-proliferative effects on human cancer cells. Food Chem. Toxicol. 2010, 48, 722-728.

2. Ahn, B.N.; Kim, J.A.; Kong, C.S.; Seo, Y.; Kim, S.K. Protective effect of (20S)-columbianetin from Corydalis heterocarpa on UVB-induced keratinocyte damage J. Photochem. Photobiol. B 2012, 109, 20-27.

3. Kim, J.J.; Kang, T.H.; Seo, J.U.; Na, H.J.; Kim, S.J.; Moon, P.D.; Kim, N.H.; Choi, I.Y.; Myung, N.Y.; Hong, S.H.; et al. Libanoridin inhibits the mast cell-mediated allergic inflammatory reaction. Immunopharmacol. Immunotoxicol. 2010, 32, 258-264.

4. Kang, K.H.; Kong, C.S.; Seo, Y.; Kim, M.M.; Kim, S.K. Anti-inflammatory effect of coumarins isolated from Corydalis heterocarpa in HT-29 human colon carcinoma cells. Food Chem. Toxicol. 2009, 47, 2129-2134.

5. Jeong, H.J.; Na, H.J.; Kim, S.J.; Rim, H.K.; Myung, N.Y.; Moon, P.D.; Han, N.R.; Seo, J.U.; Kang, T.H.; Kim, J.J.; et al. Anti-inflammatory effect of columbianetin on activated human mast cells. Biol. Pharm. Bull. 2009, 32, 1027-1031. 
6. Hata, K.; Kozawa, M.; Baba, K. Coumarins from chinese crude drug "She Huangzi," the fruits of Cnidium sp. and from Cnidium japonicum Mrq. Yakugaku Zasshi 1972, 92, 1289-1294.

7. Morikawa, T.; Matsuda, H.; Nishida, N.; Qugushi, T.; Yoshikawa, M. Structures of new aromatics glycosides from a Japanese folk medicine, the roots of Angelica furcijuga. Chem. Pharm. Bull. 2004, 52, 1387-1390.

8. Baba, K.; Kawanishi, H.; Taniguchi, M.; Kozawa, M. Chromones from Cnidium monnieri. Phytochemistry 1992, 31, 1367-1370.

9. Baba, K.; Kawanishi, H.; Taniguchi, M.; Kozawa, M. Chromone glucosides from Cnidium japonicum. Phytochemistry 1994, 35, 221-225.

10. Ma, W.G.; Fukushi, Y.; Tahara, S. Fungitoxic alkaloids from Hokkaido Corydalis species. Fitoterapia 1999, 70, 258-265.

11. Tatsuzawa, F.; Mikanagi, Y.; Saito, N.; Shinoda, K.; Shigihara, A.; Honda, T. Cyanidin glycosides in flowers of genus Corydalis (Fumariaceae). Biochem. Syst. Ecol. 2005, 33, 789-798.

12. Choi, S.U.; Baek, N.I.; Kim, S.H.; Yang, J.H.; Eun, J.S.; Shin, T.Y.; Lim, J.P.; Lee, J.H.; Jeon, H.; Yun, M.Y.; et al. Cytotoxic isoquinoline alkaloids from the aerial parts of Corydalis incise. Arch. Pharm. Res. 2007, 30, 151-154.

13. Mongan, L.C.; Jones, T.; Patrick, G. Cytokine and free radical responses of alveolar macrophages in vitro to asbestos fibres. Cytokine 2000, 12, 1243-1247.

14. Guha, M.; Mackman, N. LPS induction of gene expression in human monocytes. Cell. Signal. 2001, 13, 85-94.

15. Choi, J.H.; Park, Y.N.; Li, Y.; Jin, M.H.; Lee, J.; Lee, Y.; Son, J.K.; Chang, H.W.; Lee, E. Flowers of Inula japonica attenuate inflammatory responses. Immune Netw. 2010, 10, 145-152.

16. Zhang, X.; Xiong, H.; Liu, L. Effects of taraxasterol on inflammatory responses in lipopolysaccharide-induced RAW 264.7 macrophages. J. Ethnopharmacol. 2012, 141, 206-211.

17. Gomes, A.; Fernandes, E.; Lima, J. Fluorescence probes used for detection of reactive oxygen species. J. Biochem. Bioph. Meth. 2005, 65, 45-80.

18. Mangialasche, F.; Polidori, M.C.; Monastero, R.; Ercolani, S.; Camarda, C.; Cecchetti, R.; Mecocci, P. Biomarkers of oxidative and nitrosative damage in Alzheimer's disease and mild cognitive impairment. Ageing Res. Rev. 2009, 8, 285-305.

19. Gross, S.S.; Wolin, M.S. Nitric oxide: Pathophysiological mechanisms. Annu. Rev. Physiol. 1995, 57, 737-769.

20. Marcinkiewicz, J.; Grabowska, A.; Chain, B. Nitric oxide upregulates the release of inflamatory mediators by mouse macrophages. Eur. J. Immunol. 1995, 25, 947-951.

21. Davis, K.L.; Martin, E.; Turko, I.V.; Murad, F. Novel effects of nitric oxide. Annu Rev. Pharmacol. Toxicol. 2001, 41, 203-236.

22. Marnett, L.J. The COXIB experience: A look in the rearview mirror. Annu. Rev. Pharmacol. Toxicol. 2009, 49, 265-290.

23. Turini, M.E.; DuBois, R.N. Cyclooxygenase-2: A therapeutic target. Annu. Rev. Med. 2002, 53, 35-57.

24. Prescott, S.M.; Fitzpatrick, F.A. Cyclooxygenase-2 and carcinogenesis. Biochim. Biophys. Acta 2000, 1470, 69-78.

25. Hinz, B.; Brune, K. Cyclooxygenase-2-10 years later. J. Pharmacol. Exp. Ther. 2012, 300, 367-375. 
26. Glauser, M.P. The inflammatory cytokines. New developments in the pathophysiology and treatment of septic shock. Drugs 1996, 52, 9-17.

27. Mannel, D.N.; Echtenacher, B. TNF in the inflammatory response. Chem. Immunol. 2000, 74, 141-161.

28. Aggarwal, B.B.; Natarajan, K. Tumor Necrosis Factors: Developments during the last decade. Eur. Cytokine Netw. 1996, 7, 93-124.

29. Moncada, S.; Palmer, R.M.; Higgs, E.A. Nitric oxide: Physiology, pathophysiology, and pharmacology. Pharmacol. Rev. 1991, 43, 109-142.

30. Molloy, R.G.; Mannick, J.A.; Rodrick, M.L. Cytokines, sepsis and immunomodulation. Brit. J. Surg. 1993, 80, 289-297.

31. Kasama, T.; Miwa, Y.; Isozaki, T.; Odai, T.; Adachi, M.; Kunkel, S.L. Neutrophil-derived cytokines: Potential therapeutic targets in inflammation. Curr. Drug Targets Inflamm. Allergy 2005, 4, 273-279.

Sample Availability: Samples of the all tested compounds are available from the corresponding author.

(C) 2015 by the authors; licensee MDPI, Basel, Switzerland. This article is an open access article distributed under the terms and conditions of the Creative Commons Attribution license (http://creativecommons.org/licenses/by/4.0/). 